\begin{tabular}{cc}
\hline \hline \multirow{2}{*}{ 特集 } & $\begin{array}{l}\text { 教授定年退職 } \\
\text { 記 念 講 演 }\end{array}$ \\
\hline \hline
\end{tabular}

P. 154 堂医学 38 (1992) 生理学教室発足当時よりの電気生理学回顧**

\title{
Reminiscences of electrophysiology in the department of physiology in Juntendo University
}

\author{
竹内宣子* \\ NoRIKo TAKEUCHI, M. D.
}

\begin{abstract}
順天堂大学医学部生理学教室は, 昭和 27 年, 坂本嶋嶺教授, 真島英信助教授という先生方で, 当 時の三号館一階に発足しました。お二方の先生共今は亡く, 発足当時より教室員としてお世話に なりました者として, 古い記憶をたよりに, 生理学教室での主として当時の電気生理学と研究用 電気機器について簡単にまとめました。 その後シナプスの伝達機構を専門に研究してきました ので, その仕事の一端を報告させていただきます.
\end{abstract}

索引用 語: 順天堂大学生理学教室, 電気生理学, 神経筋接合部, 膜電位固定, アセチル コリンチャネルのイオン透過性, 伝達物質

Key words : Department of Physiology in Juntendo Univ., electrophysiology, neuromuscular junction, voltage clamp, ionic permeability of acetylcholine channel, transmitter

\section{順天堂大学生理学教室の発足}

まず, 本日とのような記念講演の機会をお与え いただきましたことを,山下会長はじめ順天堂医 学会会員の諸先生方に厚く御礼申し上げます. 退 職にあたり振り返ってみますと, 本学に生理学教 室が発足いたしてよりまさに四十年という日を迎 えたのであります.

私, 国試のあと, 神経生理学の勉強をしてみた いと思い, 東大生理の坂本研究室へ研究生として 入れていただきました. 間もなく坂本先生はで定 年で, 次いで順天堂大学の教授として生理学講座 を創設されるとのことでした. 私はぜひぜひお供 をさせていただき, 先生のもとで引き続き勉強

* 順天堂大学医学部生理学第一講座 Department of Physiology ( I ), Juntendo University School of Medicine, Tokyo, Japan

* * 第260回順天堂医学会学術集会 [Mar. 25, 1992 開催〕 [May 21, 1992 原稿受領〕
させていただきたいと願い, 願いが叶えられまし た. 坂本嶋嶺教授・真島英信助教授という最高レ ベルのすばらしい構成で, 昭和二十七年, まだ木 造の三号館一階に生理学教室は誕生しました. 当 時はまだ敗戦の混乱期の色濃く残る時代でしたが, <順天堂医学>誌に最近医史学の酒井先生がお書 きになっておられる『本郷キャンパス建物の移り 変わり』によると, 三号館・四号館は昭和二十六 年にできた建物とのこと, まだ新しくきれいでし た. 仕事はまず実験机・椅子・学生実習用機械を 購入することから始まりました. 筋収縮実験用口 タトリュームのみは, 数台備えられていましたの で, 実験可能なことから, 真島先生の筋収縮の力 学的解析ので研究がここから出発されたのです.

\section{当時の電気生理学 \\ 一電気的装置を中心に一}

神経生理学は, 当時は殆どが電気生理学といっ 
てよいのですが, 研究に必須な増幅器・記録器の 市販のものは非常に乏しく, 記録器としては, 横 河製の電磁オシロと称する電磁ガルバノメーター がよく用いられていました. ガルバに付けられた 微小な鏡に当てた光による反射光の振れを感光紙 に記録するものでした. 真島先生はこれを用いて 筋収縮による張力を, 考案された張力一電流変換 器を介して記録, 解析する研究に着手されました。 坂本先生ので研究は, 興奮性膜における電気刺激 の理論で, 大変緻密なものでしたので, それに適 する記録器がなく, 細胞の膜の局所の電位の変化 を $\mu \mathrm{sec}$, あるいは msec で切って特別のコンデ ンサーにチャーシとして貯めてから, 各瞬間のチャ 一ジを測定するという方法を採っておられました。 当時オシロスコープは工学系の高周波をみるため のものはあったと思われますが, われわれが必要 とする条件のものはまだなく, 増幅器その他の電 気器具は殆ど各自の手製でした。いかに上手に目 的にあった増幅器や電子機器を作るかが, 研究成 功の鍵であったといってよいでしょう. 当時は神 経あるいは筋組織の細胞外導出によりそれらの電 位変化を記録する仕事が大部分でしたが, 1950年 代の半ばには外国でぽつぽつ細胞内電極により細 胞の膜の電位変化を直接導出する方法が行われは じめてきました。導出条件が単純で解析が容易で すから, 是非細胞内導出をと希い, 準備をはじめ ました. 電極が細胞内に入ったとき, 静止膜電位 を測定記録するための直流増幅器と, 数十 $M \Omega$ の 電極を用いるための高入力抵抗・低グリッド電流 の入力部を組まなければなりませんでした.

当時,一種だけその条件を満たす米国製小型真 空管があり, 数個やっと入手してそれぞれ特性を 調べ, 特性のほぼ近い二個を選んで平衡型入力部 を作製しました，同時に，それらのアンプのため の定電圧 B 電源（真空管の陽極へかける +200 $300 \mathrm{~V}$ の直流電源) ・ マイナス電源・真空管のヒ一 タ一電源等も秋葉原に通いながら部品を集め, シャ ーシに穴を開けることから始めてハンダでてを振 り回しながら手製で組み上げ, どうやら $60 \mathrm{db}$ 程 度の直流増幅器が完成しました. 刺激装置も同様
に電源部・発振部・制御部と手製で組み上げまし た. そのうちに電気生理用のオシロスコープが発 売されることになってきました。しかし，その頃 の学内研究費の何年汃分という高価な価格で, 到 底購入は不可能でした。

\section{筋電図研究室の時代}

先に東大の研究生の時期に, 当時筋電図を研究 され臨床にも広く利用できるよう, 精力的に努力 されていた時実利彦先生の部屋で筋電図を少し勉 強させていただきました. 本学病院には当時まだ 筋電図の検查装置はないようでしたので, 要請が あれば筋電図の検査を引受けますから特別の予算 はいただけないものでしょうかと, 坂本先生・真 島先生にお願いしてみました. 先生方ので尽力に よりそれが実現し, オシロスコープ・小型電磁オ シロレコーダーなどが備えられ，手製の針電極・ アンプ等, 当時, 群大生理より移っててられた石 田絢子先生, 生理へ研究生として最初にはいられ た佐藤紋郎先生等にお手伝いいただいて, 筋電図 検查が可能となりました. かくて順天堂大学筋電 図研究室が真島助教授を室長として昭和二十九年 より生理学教室内に発足し, 数年間本学病院の筋 電図検查を担当しました。真島先生は脊髄反射に も興味をお持ちで, 石田先生らと共にカエルの筋 電図による脊髄機能の研究を平行してされていま した.一方, 備えられたオシロスコープを利用さ せていただき, 未梢シナプスである神経筋接合部 のシナプス電位の細胞内波形記録, および解析が 可能となりました。

\section{シナプスの生理学 \\ 一終板電位の膜電位固定一}

種々のシナプスのなかで神経筋接合部は, 実験 に有利な条件を数多く持ち, 伝達機構の解析が進 んでいたことは他に類なく, また伝達物質がアセ チルコリンであることが確定していた唯一のシナ プスでした. 支配神経を刺激し, シナプス後電位 


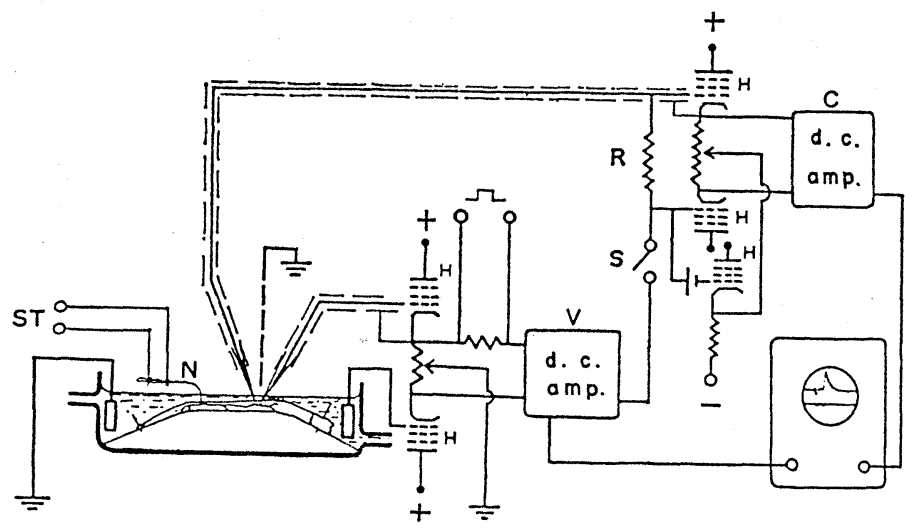

図- 1 細胞内電極を用いた膜電位固定法の回路図 $\mathrm{H}$ : 高入力抵抗, 低グリッド電流の真空管, $\mathrm{V}$ : feedback 用約5000倍の直流アン プ, C : feedback 電流記録用約 1000 倍の直流アンプ
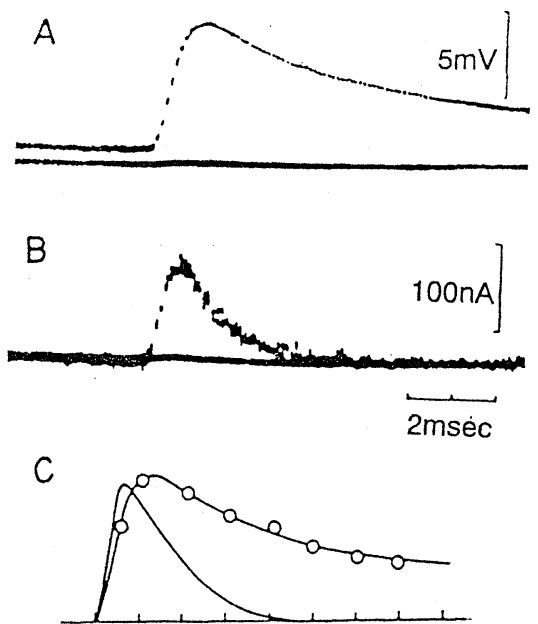

図- 2 細胞内記録による終板電位 (A) と電位固定によ り得られた終板電流 (B) の波形のオシロスコープ像

である終板電位を終板部から導出，そのオシロス コープ波形を写真記録するという方法でシナプス 伝達時の, 筋伸張による促進効果, 温度変化によ る伝達物質放出量の変化等を追求しました. シナ プス後電位は, シナプス前神経終末から放出され た伝達物質が後シナプス膜のレセプターに結合, 活性化してチャネルを開くことにより後シナプス 膜のコンダクタンスが増加, そこを流れる電流が 隣接部を流れるため, 後シナプス細胞の脱分極が
起とりシナプス電位として記録され るものです. 従ってその電位は, シナ プス隣接部膜の電気的性質に依存し た影響を受けますから, 実際の伝達物 質の放出量や, 作用している時間経過 を正確に表すものではないのです.

1952年頃よりイギリスでは, Hodgkin らにより, イカの巨大神経に縦に 細い銀線電極を通し, 神経の膜を電位 固定することによって, 興奮すなわち 活動電位とは, 膜の脱分極によりナト リウムコンダクタンスの一過性上昇 (Na-channel が open), 次いでカリウ ムコンダクタンス上昇 (K-channel が open）が起てることであるという， いわゆるナトリウム説を基礎付ける仕事が次々と 発表されました。この膜電位固定法を終板部に適 用できるなら, 実際にアセチルコリンが作用して いる時間経過などが分かるはずです。しかし終板 には, 細胞内電極という高抵抗の電極を使わなけ ればなりませんから, 原理は negative feedback という簡単なものであっても, 実際に可能 かどうか心配であったのですが，試みることにし ました. 図-1 は当時用いた電気回路図を示したも のです. V は 5〜6000倍の feedback 用直流アン プで, 真空管でてれを組むのはかなり大変でした。 全ての電源を定電圧とし, 別に定電流ヒータ一電 源を組んで全ての真空管のヒーターを直列に流す というようなととを試みましたが, 平衡型アンプ のバランスの崩れやドリフトに常に悩まされまし た. また feedback 電流の記録法も何回か改良し, 発振と闘いながらやっと電位固定に成功して, 神 経筋伝達時の終板電流の記録が可能になりました。 図- 2 のA がその波形の一例です. 同一終板で feedback をはずして記録した通常の終板電位力泪$2 \mathrm{~A}$ の波形であり，時間経過がかなり異なります. $\mathrm{C}$ は B の時間経過の電流が終板を流れたとして, 周囲の筋線維膜の時定数・実効膜抵抗等を測定後 それらの数值を用い, 計算でもとめた各瞬間の電 位変化 $(\bigcirc)$ と実測された終板電位の経過がよく 

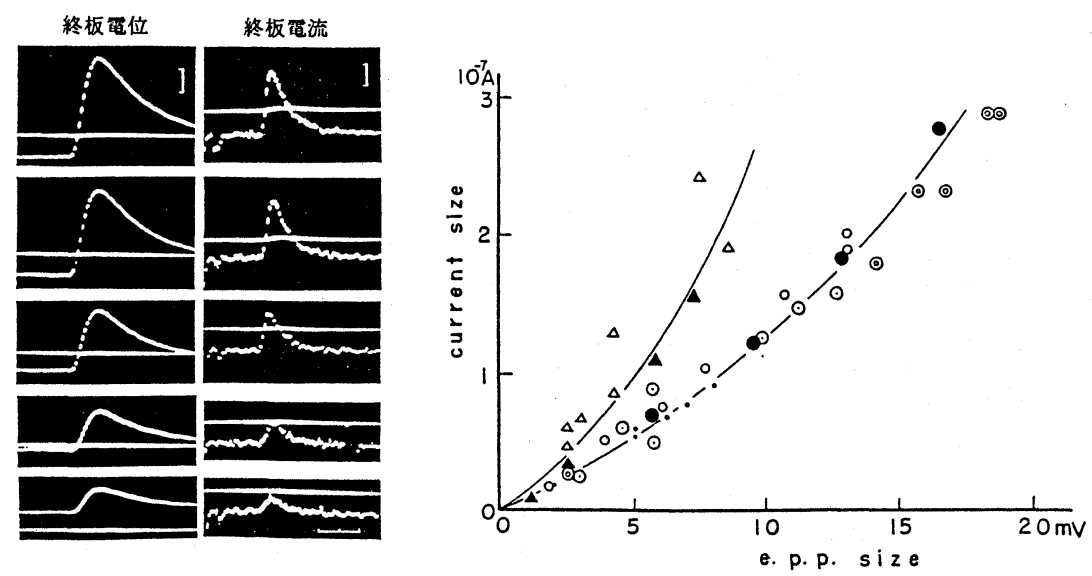

図- 3 終板電位の大きさとそれに対応する終板電流の大きさとの関係 左図 : ある単一終板でクラーレの濃度を変えて得られた種々の大きさの終板電位と終板電流. 右図 : 終板電位と終板電流の振幅の関係. 同一印は同一終板からのデータ.

一致することを示したものです. B に示される feedback 電流の経過は, 神経終末から放出された 伝達物質アセチルコリン分子が終板に働き，多く のアセチルコリンチャネルを開いてイオン透過性 が増大した経過に他なりません，種々の大きさの 終板電位と, それを電位固定して得られた終板電 流の大きさとの関係は図-3から明らかなように， 数 $\mathrm{mV}$ 以下を除くと直線関係にはなく, シナプ ス電位の大きさのみを伝達の指標とする時はこの 点への留意が必要です. 電位固定する膜電位を種々 に変えて調べると, 一般興奮性膜のナトリウムチャ ネルと異なり,アセチルコリンによる電流は膜電 位とともにほぼ直線的に振幅が変わること, 膜電 位座標上で電流零となる点（平衡電位または逆転 電位）は, 正常リンゲル中では約 $-15 \mathrm{mV}$ ，それは 外液の $\mathrm{Na} \mathrm{K}$ などの陽イオン濃度に依存して変 化すること, CI を膜は不透過と考えられる陰イオ ンで置換すると, 筋線維の膜電位は大きく変わる が終板電流の逆転電位は全く変わらないとと等が 明らかになりました。これらは, 終板のアセチル コリンチャネルは陽イオン選択透過性であること を意味します.Ca イオンは僅かに透過しますが, 外液に Na イオンが十分あるときはチャネルを 通過する Na イオンと何れかのサイトで, interac- tion のあることが実験結果から示唆され, アセチ ルコリンにより開くチャネルは, 単に通過イオン の大きさを規定する, 表面が陰性荷電の孔という のみではないととが考えられます。

細胞内電極を用いてシナプス部の電位固定を, 当時の真空管の増幅器を用いて行うのは, 電気機 器の素人としてはなかなか大変でしたが, それを 成功しえたのは, 秋葉原に近くて電気部品の入手 が容易であったという本学の地の利によるものが 大きかったと思っております. 昭和三十四年渡米 後は第一生理所属となり, 帰国後, 当時の竹内昭助 教授と再び同様の装置を電源から組み上げました。

\section{一伝達物質候補としてのグルタミン酸の発見—}

上記の実験はカエルの骨格筋で行ったものです が, 陰イオンについての実験では不透過の陰イオ ンとして主にグルタミン酸イオンを用いました. サイズの大きい陰イオンのなかで純度のよいもの の入手が容易で, 比較的キレート作用が弱かった からです. 幸いなととにカエル筋では特殊な作用 はみられませんでしたが, 何かグルタミン酸を用 いたというレポートがあるかもしれないと文献を 探したところ,ザリガニの筋では非常に低濃度で 


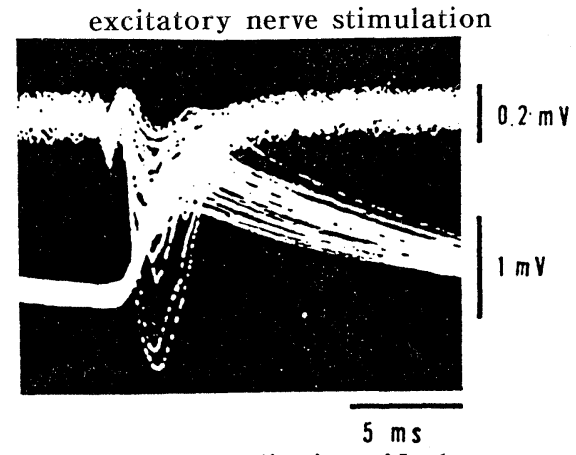

ionophoretic application of L-glutamate

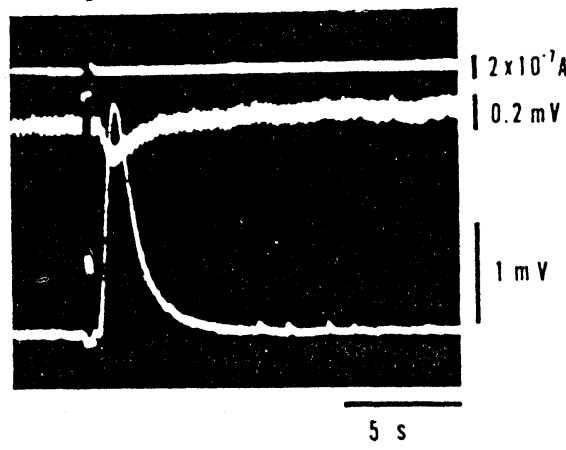

図- 4 ザリガニ骨格筋, 単一神経筋接合部に対する Lグルタミン酸の効果

$\mathrm{A}$ : 興奮性神経頻回刺激による接合部局所電流（上のビーム） と細胞内導出の興奮性シナプス電位 (下のビーム), B : 微小ピ ペットから電気泳動パルス (最上ビーム) によりその局所に与 えられた L-グルタミン酸による同一点からの記録.

強い収縮が起こるという報告がありました。そと でまず,ザリガニの神経筋接合部に対するグルタ ミン酸の作用を調べてみることにしました.ザリ ガニの神経筋接合部は脊椎動物の中枢神経に似て, 興奮性と抑制性の神経支配で構成され, 筋線維は 多接合部性です.図-4亿示されるように, 興奮性 神経を刺激しながら細胞内電極と同様の微小電極 を筋線維表面にあて, シナプス電流の記録される 数ミクロンの部位では, L-グルタミン酸をつめた 微小電極から電気泳動的に与えられた微量のグル タ々ン酸に鋭敏に応じ, シナプスを流れる電流が 記録されたのです.その他の部位では全くなんの 応答もないてと,グルタミン酸を与え過ぎて脱感 作 (desensitization) が起こると, 同時に神経
刺激によるシナプス電位も小さくなること,すな わち, 神経からの伝達物質とグルタミン酸のレセ プターは同一であるとと等も確認され，L-グルタ ミン酸はザリガニの神経筋接合部では, 興奮性伝 達物質の候補であることを提案しました. 1960年 代の始めです.

1960年代の後半, 真空管がトランジスターとな り, トランジスターの回路を使った小さいモシュー ルの OP アンプができ, 素人でも容易に種々の性 能のアンプあるいは回路を組むととができるよう になり, 細胞内電極を用いたシナプスの電位固定 も世界のあちこちで行われるようになりました。 光学機器・刺激装置・各種増幅器・オシロスコー プ, その他の記録器も既製のものが豊かに市販さ れ, 研究費さえ十分であるならば楽に実験できる 時代にはいりました。

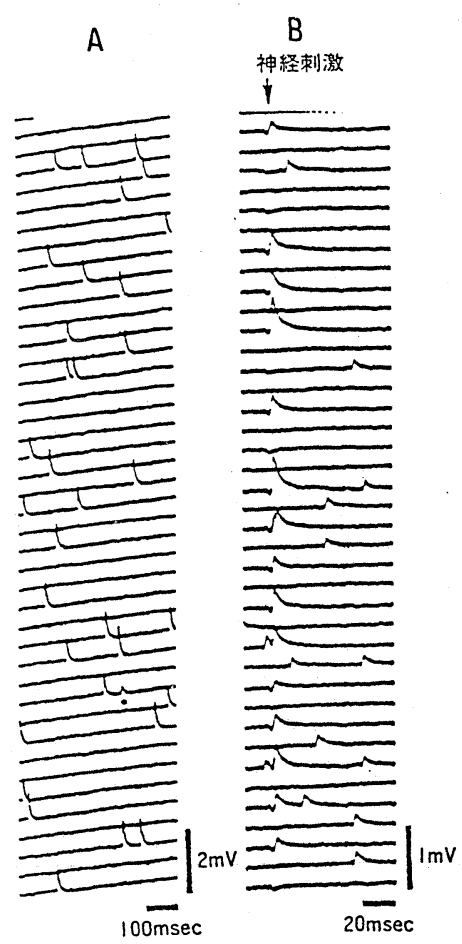

図- 5 自発性微小終板電位と低 $\mathrm{Ca}$ 液中での神経刺激 亿よる終板電位の記録例

A : カエル胸皮筋静止時の自発性微小終板電位. B : カエル縫工 筋, 低 $\mathrm{Ca}$ 液中での自発性微小終板電位 と神経刺激による終板 電位. 


\section{一伝達物質放出機構についての研究—}

脊椎動物の神経筋接合部はシナプス前要素・シ ナプス後細胞 1：1の単純な構造を持ち, 伝達物 質放出単位（伝達物質素子）としての微小終板電 位の記録が容易で, 伝達物質放出機構の研究にも 適したシナプスであります. 終板部の細胞内記録 により静止時, 図- 5.A のような振幅のほほ揃つ た自発性の微小終板電位が時々観察されます. B

は外液の $\mathrm{Ca}$ 濃度を0.2mM 程度に減らして支配 神経を刺激し, 終板電位を微小終板電位と共に記 録したオシロスコープ写真です. 振幅はばらつき が大きいが, 各々は微小終板電位のほぼ整数倍で あることが分かります.神経終末に興奮が達する と伝達物質はこの素子を単位として, $\mathrm{Ca}$ ion の 流入量に応じて同期して放出されると考えると, 伝達物質の放出量は素子の数で量的に表現でき ます.図-6.A は単一接合部で, $\mathrm{Ca}$ 濃度を $0.1 \mathrm{~m}$ $\mathrm{M}$ から少しずつ上げたとき得られた各濃度での, 神経刺激時の平均素子数と $\mathrm{Ca}$ 濃度との関係です. 外液 $\mathrm{Ca}$ 濃度の僅かな増加により伝達物質放出量 は著明に上昇し，その勾配の急峻なととは, 膜外 から流入する $\mathrm{Ca}$ が伝達物質の放出を起こす過程 のいずれかで, 協調作用 (cooperativity) があ ることを示すものです.一方, 自発性素子の 放出はその平均頻度を用いて放出量を正確に 表現できるので, 外液の $\mathrm{Ca}$ 濃度を変え放出 量の変化を相対的平均頻度としてグラフに表 したものか泪-6.B です. 正常リンゲル液 (K $2.5 \mathrm{mM})$ では変化はゆるやかですが, 外液 $\mathrm{K}$ を少しずつ増し神経終末を脱分極させてゆく と, $\mathrm{Ca}$ 濃度と放出量の関係はだんだん急峻に なってゆくのが分かります. 神経終末に興奮 が達した時の大きい脱分極による放出に近付 いてゆくのだと思われます.また終末の脱分 極の程度により, 放出サイトの総数がまして ゆくこと, Ca ion に対する見かけの解離常数 が減少してゆくこと等が示唆されています.

てのような単一シナプスで条件を変えなが ら長時間記録をとる実験は, 1970年代はオシ
ロスコープの掃引波形を $30 m$ フィルムの連続撮影 カメラで記録していましたが, 70年の後半からは FM データーレコーダーに連続記録するようにな り,さらに80年代なかばになりますと, digital audio processor (PCM) と家庭用 video cassette recorder に少し手を入れて改造し, 周波数帯域が 直流から $20 \mathrm{KHz}$ の廉価な連続記録器が使えるよ うになってきました。 そてで静止時の自発性伝達 物質素子の放出の長時間連続記録により, 放出時 点を点過程として統計学的に時系列解析を試みま した. 中央電算機室分室の PDP-11の時代にコン ピューターを使わせていただき, 電算機室の江原 さん, 教室の八名さん, 後半は輪湖さん・筥さん の諸氏にプログラムなどお世話になりました，図7 は正常リンゲル液での静止時, 定常状態の自発 性素子放出時点あるいはその間隔の時系列統計の いくつかと,その結果についてのポアソン性の検 定とを示したものです. それらは, 定常な data であるならばポアソン性を有意に否定するものは なく, すなわちその生起はランダムで, 個々の放 出は後に履歴効果または aftereffect を残さず, 互いに独立であることを意味します。他方，ての 自発性放出のレベルを上げるような条件として,
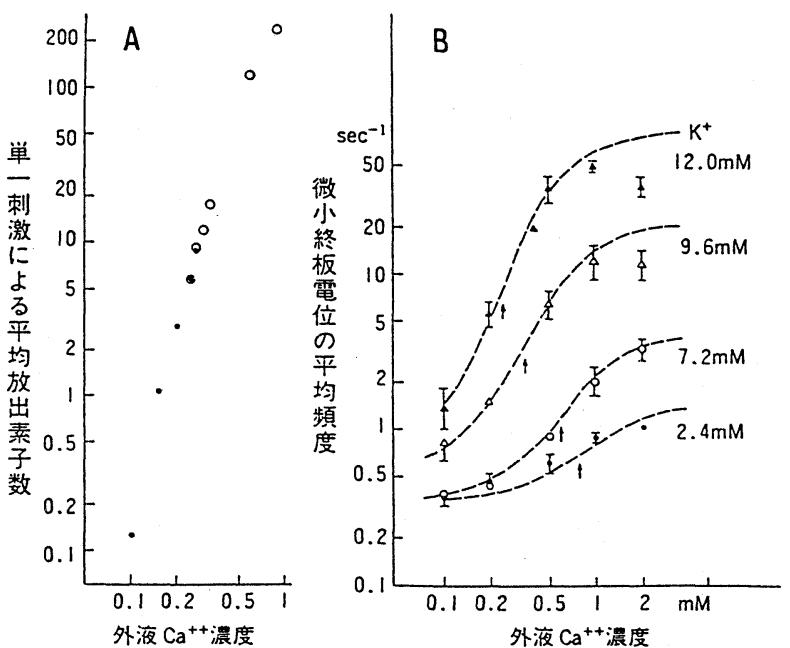

図- 6 外液 $\mathrm{Ca}$ 濃度と伝達物質素子放出との関係 $\mathrm{A}: \mathrm{Ca}$ 濃度と神経刺激による平均放出素子数との関係. 黒丸は終板電 位の素子数, 白丸は終板電流より計測.

$\mathrm{B}: \mathrm{Ca}$ 濃度と 4 種の $\mathrm{K}$ 濃度レベルにおうる自発性放出素子の平均頻 度との関係. 
normal Ringer
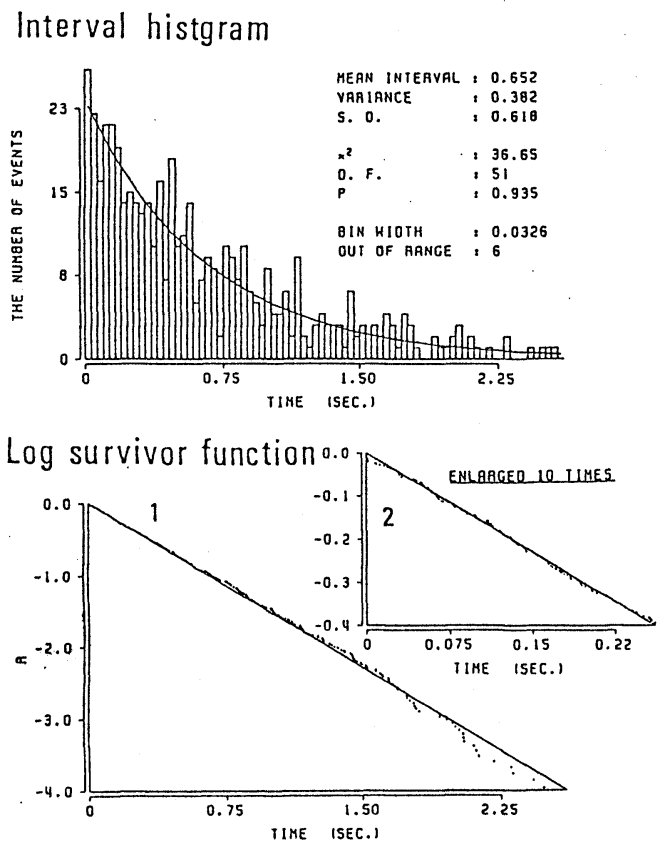

Intensity function

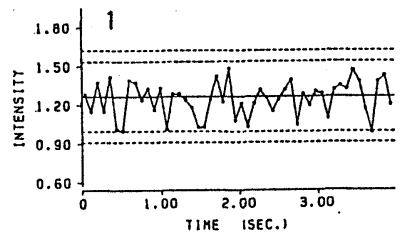

図- 7 正常リンゲル液中の定常状態での自発性素子放出の時 系列解析

単一接合部からの連続記録をコンピュータ, PDP11／60で統計解析し， ポアソン性の検定を行った結果のプロッター出力の数例. 強度関数 (intensity function), 変動一時間曲線 (variance-time curve) にお引る 年 点線は, 内側 $5 \%$, 外側 $1 \%$ の有意水準を示す.

外液のK 濃度を $12 \mathrm{mM}$ 亿増した場合およびカフェ イン, またはテオフィリンを作用させた場合は， 図-8に見られるように統計量によってはランダ ム性から外れるものが見いだされました。特に放 出間隔のヒストグラムにおいて, 高 $\mathrm{K}$ 液中では最 短の部分がポアソン過程とした場合の理論値より 有意に少なく,テオフィリン処置の場合は有意に 多いとと, 同様に強度関数（それぞれ個々の素子 放出後の放出確率の時間的変化）において, 放出
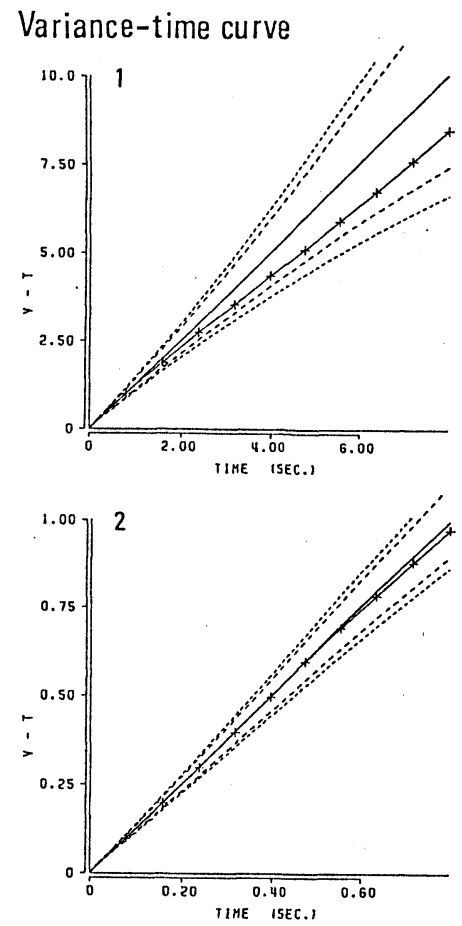
$+1 \mathrm{mM}$ theophylline

Interval histgram

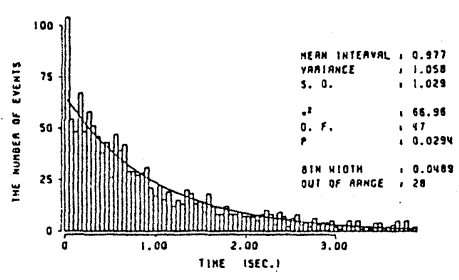

$12 \mathrm{mM}-\mathrm{K}^{+}$

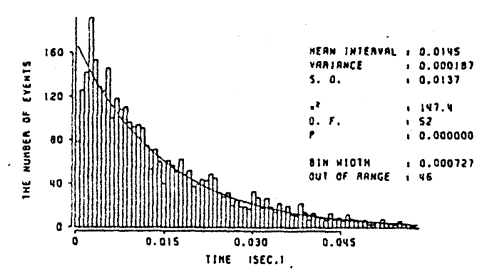

Log survivor function
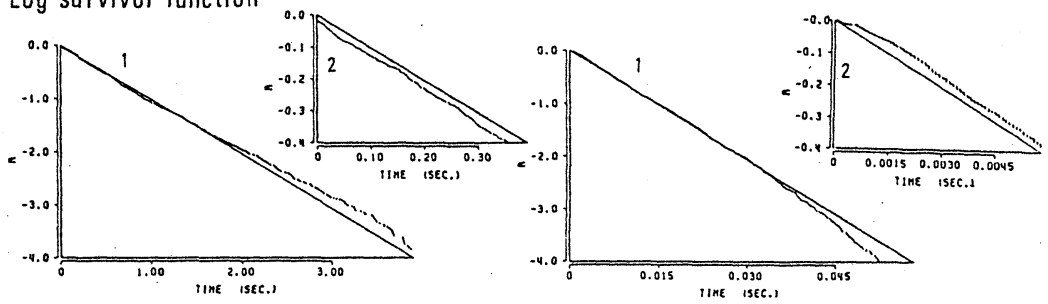

Intensity function
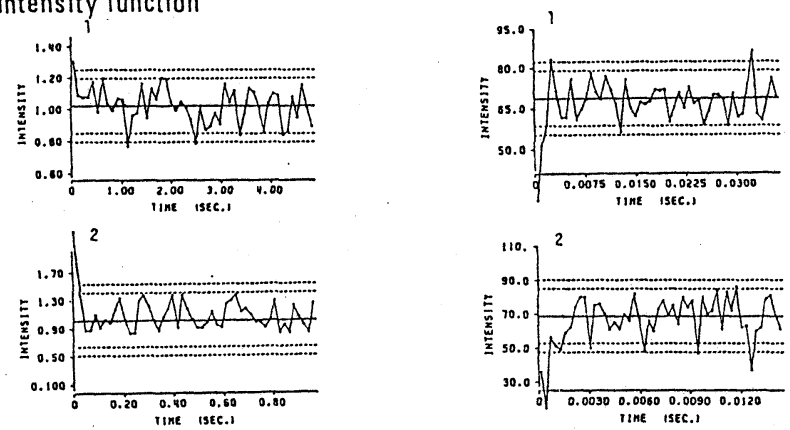

\section{Variance-time curve}
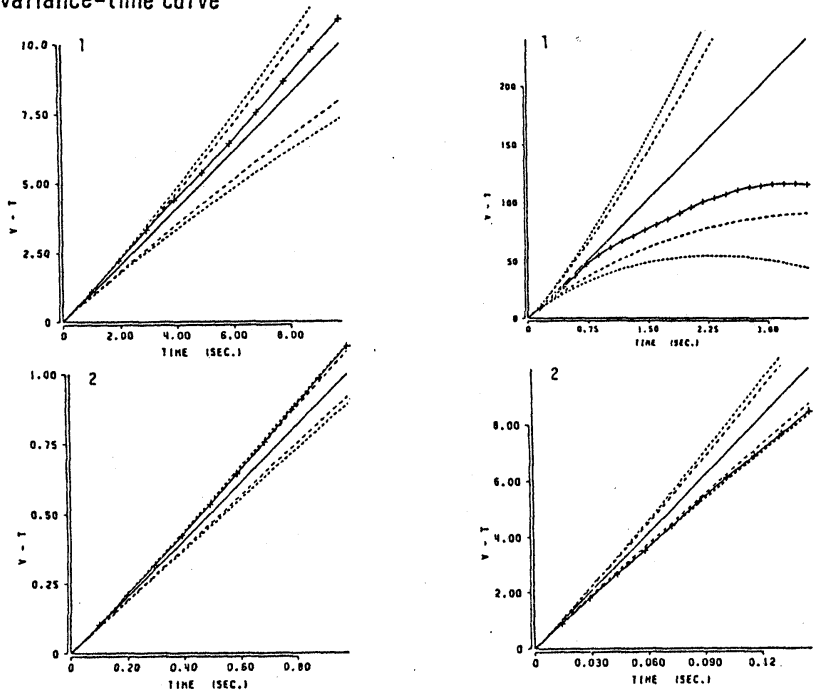

図-8 1 mM-テオフィリンおよ び12mM-K+により素子放出頻度 を増加させた場合の, 図- 7 と同 様の統計解析. 


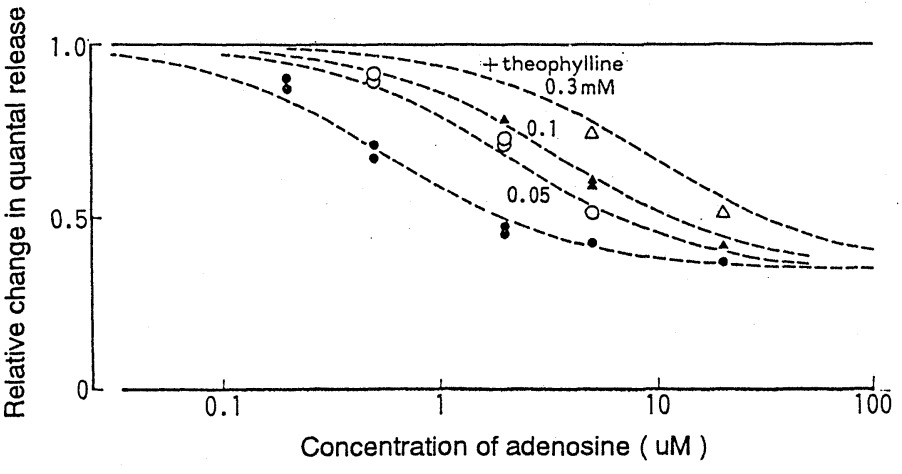

図- 9 伝達物質放出にたいするアデノシンとテオフィリンの相互作用

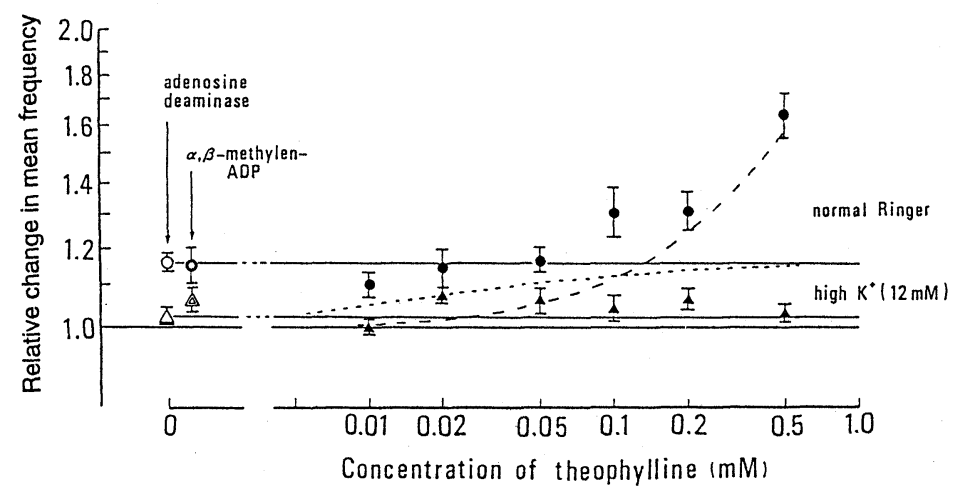

図-10 静止時自発性素子放出の低濃度テオフィリンによる増加と, アデノシ ンデアミネイスにより内在性アデノシンを分解した場合の増加との比較
て右へ平行移動し, 競合抑制して いることを示しています.テオフィ リンのアデノシンレセプターに対 する抑制の解離定数は, この場合 $0.03 \mathrm{mM}$ でした. カフェインを用 いた場合のそれは $0.06 \mathrm{mM}$ という やや高い值でした. 正常リンゲル 中での静止時, この濃度近辺のテ オフィリンを単独で与えて伝達物 質素子の放出への影響をみたもの が図-10です.テオフィリン0.03〜 $0.05 \mathrm{mM}$ の辺りで, 自発性の伝達 物質放出は約10\%増加しています。 この増加の程度は同一接合部で, アデノシンを分解する酵素ーアデ ノシンデアミネイスを作用させた 場合と一致し, それは内在性のア デノシンによって, 常時放出がモ ジュレイトされている部分である ことを示すものであります. 同様 な実験結果は, 神経刺激による伝 達物質放出量（平均素子数）につ いても得られました. 伝達物質放 出に関するこれら薬理学的な仕事 は, 教室の滝川さんに協力してい
しれないと思われることを一薬理学で恐縮です が一拉話して終わりに致したいとおもいます。近 年アデノシンという物質は, 常に生体内に存在し て各種組織 - 平滑筋, 心筋をはじめ中枢神経系, 種々のシナプスにおいてその機能をモジュレイト しているてとが知られておりますが,カフェイン・ テオフィリンはそのアデノシンのレセプターのア ンタゴニストであります.神経筋接合部において 伝達物質素子の放出量を正確に測定しながら, 種々 の濃度のアデノシンを外液に与えてみると, 濃度 依存性に自発性素子放出は減少し, その抑制効果 の half-maximum は平均 $0.8 \mu \mathrm{M}$ 程度です.ア デノシンの潅流液中にテオフィリンを加えてその 効果をみたすものが図-9です.アアデノシンの濃度抑制効果曲線は加えたテオフィリンの濃度に応じ
ただいたものです.このような内在性のアデノシ ンによる抑制は, おそらく広く中枢神経系のシナ プスにおいても働いているものと思われ，てのア デノシンによる抑制が取れると多少脳も元気に機 能するのではないかなと思い,コーヒ一を愛用し ております。

大変準備も悪く,下手な話をで静聴いただきま してありがとうございました.てのような席から ではでざいますが, 長い長い間お世話になってま いりました大学の諸先生方, 事務の方々そして生 理学教室の, 今は亡き坂本先生・真島先生をはじ めとして, 何事につけても色々と支えていただい た教室員の方々に, 心から感謝を捧げたいと存じ ます. 最後们順天堂大学のますますので発展をお 祈り申し上げます。 